\title{
Detection of the phosphorylation of the estrogen receptor alpha as an outcome of GPR30 activation
}

Book or Report Section

Accepted Version

Clark, S., Pollard, K., Rainville, J. and Vasudevan, N. (2015) Detection of the phosphorylation of the estrogen receptor alpha as an outcome of GPR30 activation. In: Eyster, K. M. (ed.) Estrogen receptors: methods and protocols. Methods in Molecular Biology, 1366. Humana Press, New York, pp. 457470. ISBN 9781493931262 doi: https://doi.org/10.1007/978-14939-3127-9_36 Available at http://centaur.reading.ac.uk/58940/

It is advisable to refer to the publisher's version if you intend to cite from the work. See Guidance on citing.

To link to this article DOI: http://dx.doi.org/10.1007/978-1-4939-3127-9_36

Publisher: Humana Press

All outputs in CentAUR are protected by Intellectual Property Rights law, 
including copyright law. Copyright and IPR is retained by the creators or other copyright holders. Terms and conditions for use of this material are defined in the End User Agreement.

\section{www.reading.ac.uk/centaur}

\section{CentAUR}

Central Archive at the University of Reading

Reading's research outputs online 
Detection of the phosphorylation of the Estrogen Receptor $\alpha$ as an outcome of GPR30 activation

Sara Clark ${ }^{1}$, Kevin Pollard ${ }^{2}$, Jennifer Rainville ${ }^{1}$ and Nandini Vasudevan ${ }^{1,2^{*}}$

1. Department of Cell and Molecular Biology, Tulane University, New Orleans, LA 70118.

2. The Neuroscience Program, Tulane University, New Orleans, LA 70118.

*Corresponding author:

Dr. Nandini Vasudevan

Dept of Cell and Molecular Biology, Tulane University, 2000 Percival Stern Hall, New Orleans, LA 70018

Email: nandini@tulane.edu

Running head: Western blotting for phosphorylated ER $\alpha$ regulated by GPR30 


\section{i. Summary}

Phosphorylation of the serine residues in estrogen receptor (ER) $\alpha$ is important in transcriptional activation. Hence, methods to detect such post-translational modification events are valuable. We describe, in detail, the analysis of the phosphorylated ER $\alpha$ by electrophoretic separation of proteins and subsequent immuno-blotting techniques. In particular, phosphorylation of the ER $\alpha$ is one possible outcome of activation of the putative membrane estrogen receptor (mER),

GPR30. Hence, phosphorylation represents a crosstalk event between GPR30 and ER $\alpha$ and may be important in estrogen-regulated physiology.

ii. Keywords: phosphorylation, serine, nuclear receptor, antibody, tissue, lysate, cell line, GPR30, ER $\alpha$ 


\section{Introduction}

Steroid hormones bind to nuclear receptors, which then act as ligand-dependent transcription factors, typically termed as a slow, genomic mode of action $(1,2)$. However, steroid hormone ligands can also modify nuclear receptors rapidly (3) though the consequences of such modification are often unclear (4-6). For example, estrogen, or the natural ligand, $17 \beta$-estradiol (E2), can induce phosphorylation of the estrogen receptor $(\mathrm{ER}) \alpha(7,8)$ or reduce palmitoylation of ER $\alpha$ in CHO cells (9). The majority of phosphorylation sites on ER $\alpha$ are on the serines in the N-terminal AF-1 region; mutation of this region leads to a loss in phosphorylation of ER $\alpha$ (10). Two such serine residues are serine at 118 (S118), thought to be phosphorylated by ERK $(\mathbf{1 1 , 1 2 )}$ or cdk7 and at serine 167 (S167), thought to be phosphorylated by Rsk (13) or Akt (14). Phosphorylation at serine S118 directs coactivator recruitment and increases gene transcription (15). Phosphorylation at this site has been implicated in endocrine therapy to breast cancer $(16,17)$.

Most of the previous work has focused on the E2-mediated phosphorylation of ER $\alpha$, which is presumed to occur subsequent to the binding of the ligand to the $\operatorname{ER} \alpha(11,18)$. Alternatively, ER $\alpha$ could be phosphorylated in a ligand-independent manner by growth factors (19-21). We have shown previously that the phosphorylation of the ER $\alpha$ at serine 118 occurs rapidly within

10 minutes on the administration of $10^{-9} \mathrm{M}$ E2 in the SK-N-BE(2)C neuroblastoma cell line (22). In addition, we have also shown that a membrane-limited conjugate, E2-BSA $\left(10^{-8} \mathrm{M}\right)$, can rapidly increase phosphorylation of the $\mathrm{ER} \alpha$ at $\mathrm{S} 118$ in this cell line within 20 minutes of administration, suggesting that a) plasma membrane-initiated signaling is sufficient to phosphorylate the ER $\alpha$, and b) that the ER $\alpha$ can be phosphorylated in a ligand-independent 
manner in a neural cell line (22). Such membrane-initiated actions by E2 could occur via a putative membrane ER, the GPR30 $(\mathbf{2 3 , 2 4})$, which is a former orphan G-protein coupled receptor, localized widely in the rodent central nervous system (25). The actions of GPR30 can be studied with a selective agonist, G-1 (26), in tandem with the selective antagonists, G-15 (27) or G-36 (28), that do not bind the full-length ER $\alpha$. Our study has shown that a single injection

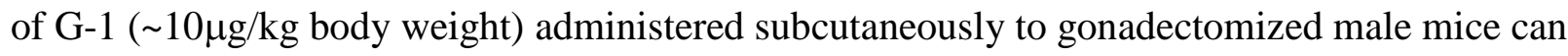
induce the phosphorylation of the $\mathrm{ER} \alpha$ at $\mathrm{S} 118$ in the ventral hippocampus within 30 minutes (29). A number of investigators have used polyacrylamide gel electrophoresis and subsequent transfer onto membranes for detection of phosphorylated ER $\alpha$, followed by detection of total $\mathrm{ER} \alpha(30-32)$. However, though detection of $\mathrm{ER} \alpha$ at $\mathrm{S} 118$ is fairly routine (33), it has been fairly difficult to detect total full-length $(66 \mathrm{kd}) \mathrm{ER} \alpha$ in the rodent brain due to the quality of the antibodies (34). We present here a protocol for detection of phospho-ER $\alpha$ from cell lines or from brain tissue that utilizes western blotting.

\section{Materials}

\subsection{Components for Creating Lysates}

1. 5X RIPA buffer (Radioimmunoprecipitation assay buffer: $50 \mathrm{mM}$ Tris- $\mathrm{HCl}, 150 \mathrm{mM}$ $\mathrm{NaCl}, 1 \% \mathrm{NP}-40,0.5 \%$ sodium deoxycholate, and 0.1\% SDS, pH $7.4 \pm 0.2$ ).

2. Protease Inhibitor Cocktail (Sigma Chemical Co).

3. Phosphatase Inhibitor Cocktail 2 (Sigma Chemical Co).

4. Phosphatase Inhibitor Cocktail 3 (Sigma Chemical Co). 
5. Complete Lysis Buffer: (see Note 1) Combine $1 \mathrm{~mL}$ of $5 X$ RIPA Buffer, $50 \mu \mathrm{L}$ Protease Inhibitor Cocktail, 50 $\mu \mathrm{L}$ Phosphatase Inhibitor Cocktail 2, and 50 $\mu \mathrm{L}$ Phosphatase Inhibitor Cocktail 3 with enough double-distilled water $\left(\mathrm{ddH}_{2} \mathrm{O}\right)$ to bring the final volume to $5 \mathrm{~mL}$. Store at $4^{\circ} \mathrm{C}$ for up to one week.

6. Phosphate-Buffered Saline (see Note 2).

7. Cell Scrapers for making lysates from cell cultures (see Note 3).

8. Kimble-Chase Kontes ${ }^{\mathrm{TM}}$ Pellet Pestle ${ }^{\mathrm{TM}}$ for making lysates from tissue (see Note 4).

9. Laemmli's SDS-Sample Loading Buffer (4X, reducing) (Boston BioProducts): $375 \mathrm{mM}$ Tris-HCl, 9\% SDS, 50\% glycerol, 9\% $\beta$-mercaptoethanol and $0.3 \%$ bromophenol blue, pH 6.8.

\subsection{SDS Polyacrylamide Gel Components}

1. Resolving gel buffer: $1.5 \mathrm{M}$ Tris- $\mathrm{HCl}, \mathrm{pH} 8.8$. Weigh out $18.17 \mathrm{~g}$ of Tris Base and place in a beaker. Add $80 \mathrm{~mL}$ of $\mathrm{ddH}_{2} \mathrm{O}$ and mix. Place buffer into refrigerator until it reaches $4^{\circ} \mathrm{C}$. Adjust using $\mathrm{HCl}$ (see Note 5) until $\mathrm{pH}$ is 8.8 while the buffer is $4^{\circ} \mathrm{C}$. Bring volume to $100 \mathrm{~mL}$ using $\mathrm{ddH}_{2} \mathrm{O}$. Store at $4^{\circ} \mathrm{C}$.

2. Stacking gel buffer: $0.5 \mathrm{M}$ Tris- $\mathrm{HCl}, \mathrm{pH} 6.8$. Weigh out $6.06 \mathrm{~g}$ of Tris Base and place in a beaker. Add $80 \mathrm{~mL}$ of $\mathrm{ddH}_{2} \mathrm{O}$ and mix. Place buffer into refrigerator until it reaches $4^{\circ} \mathrm{C}$. Adjust using $\mathrm{HCl}$ until $\mathrm{pH}$ is 6.8 while the buffer is $4^{\circ} \mathrm{C}$. Bring volume to $100 \mathrm{~mL}$ using $\mathrm{ddH}_{2} \mathrm{O}$. Store at $4^{\circ} \mathrm{C}$.

3. $30 \%$ Acrylamide/Bis solution (29:1).

4. $10 \%$ SDS: Weigh out $10 \mathrm{~g}$ of sodium dodecyl sulfate and place in a beaker. Add $80 \mathrm{~mL}$ of $\mathrm{ddH}_{2} \mathrm{O}$ and mix. Adjust volume to $100 \mathrm{~mL}$ with $\mathrm{ddH}_{2} \mathrm{O}$. Store in a closed container at room temperature (see Note 6). 
5. $10 \%$ APS: Weigh out $10 \mathrm{~g}$ of ammonium persulfate and put into a beaker. Add $80 \mathrm{~mL}$ of $\mathrm{ddH}_{2} \mathrm{O}$ and mix. Adjust volume to $100 \mathrm{~mL}$ with $\mathrm{ddH}_{2} \mathrm{O}$. Aliquot and store at $-20^{\circ} \mathrm{C}$. Only use freshly thawed aliquots and replace all aliquots after 6 months of storage.

6. N,N,N',N'-Tetramethylethylenediamine.

\subsection{Immunoblotting Components}

1. Immobilon-P PVDF Membrane, $0.45 \mu \mathrm{m}$ (see Note 7) (EMD Millipore).

2. Running Buffer: To make 10X Running Buffer stock, weigh out 288g glycine, 60g Tris base, and $20 \mathrm{~g}$ sodium dodecyl sulfate. Add to a flask containing $1.5 \mathrm{~L} \mathrm{ddH}_{2} \mathrm{O}$ and mix. When all components are dissolved, bring volume up to $2 \mathrm{~L}$ with $\mathrm{ddH}_{2} \mathrm{O}$. Store $10 \mathrm{X}$ Running Buffer in a closed container at room temperature.

3. To make 1X Running Buffer, add 100mL of 10X Running Buffer stock to $900 \mathrm{~mL}$ of $\mathrm{ddH}_{2} \mathrm{O}$. 1X Running Buffer may be filtered after use and reused up to 4 times and stored at room temperature.

4. Transfer Buffer: To make 10X Transfer Buffer stock, weigh out 288g glycine and 60g Tris base. Add to a flask containing $1.5 \mathrm{~L} \mathrm{ddH}_{2} \mathrm{O}$ and mix. When all components are dissolved, bring volume up to $2 \mathrm{~L}$ with $\mathrm{ddH}_{2} \mathrm{O}$. Store $10 \mathrm{X}$ Transfer Buffer in a closed container at room temperature.

5. To make $1 \mathrm{X}$ Transfer Buffer, combine $100 \mathrm{~mL}$ of $10 \mathrm{X}$ Transfer Buffer stock with $200 \mathrm{~mL}$ of methanol and $700 \mathrm{~mL}$ of $\mathrm{ddH}_{2} \mathrm{O}$. Store and use $1 \mathrm{X}$ Transfer Buffer at $4^{\circ} \mathrm{C}$.

6. TTBS (Tween-Tris buffered saline): To make 5x TBS stock, weigh out $87.7 \mathrm{~g}$ of $\mathrm{NaCl}$ and 12.1g of Tris Base. Mix with 1.5 $\mathrm{L} \mathrm{ddH}_{2} \mathrm{O}$. Adjust $\mathrm{pH}$ to 7.4-7.5 with $\mathrm{HCl}$. Bring volume to $2 \mathrm{~L}$ with $\mathrm{ddH}_{2} \mathrm{O}$. Store at room temperature.

7. To make $1 \mathrm{X}$ TTBS, combine $800 \mathrm{~mL} \mathrm{ddH}_{2} \mathrm{O}, 200 \mathrm{~mL}$ of $5 \mathrm{X}$ TBS, and $1 \mathrm{~mL}$ Tween-20. 
8. Blocking Solution: Weigh $5 \mathrm{~g}$ of bovine serum albumin and mix into $90 \mathrm{~mL}$ of $1 \mathrm{X}$ TTBS. Adjust volume to $100 \mathrm{~mL}$. Store at $4^{\circ} \mathrm{C}$ when not in use. Do not keep for more than 3 days.

9. Mini PROTEAN 3 or Tetra Running and Blotting Modules (Bio-Rad).

10. Plastic Containers (see Note 8).

11. Gel Blot Paper: $15 \times 20 \mathrm{~cm}$ sheets can be quartered to create 4 perfectly sized piece of blot paper.

12. Pre-stained Protein Standards/Ladder.

13. 1.0mm glass spacer plates, short plates, and casting module (Bio-Rad).

14. Water-saturated isobutanol.

\subsection{Antibodies and Stripping Buffer}

1. Rabbit anti-phospho-ER $\alpha$ (Ser 118) antibody (SC-12915-R, Santa Cruz Biotechnology).

2. Rabbit anti-phospho-ER $\alpha$ (Ser 167) antibody (sc-101676, Santa Cruz Biotechnology).

3. Rabbit anti-ER $\alpha$ antibody (sc-7207, Santa Cruz Biotechnology).

4. Goat anti-Rabbit IgG, HRP-linked antibody (see Note 9) (7074S, Cell Signaling Technologies).

5. Harsh Stripping Buffer as described by Abcam. To make $100 \mathrm{~mL}$, use $20 \mathrm{~mL}$ of $10 \%$ SDS, $12.5 \mathrm{~mL}$ of 0.5M Tris-HCL, $\mathrm{pH} 6.8,67.5 \mathrm{~mL}$ ultrapure water. Add 0.8 mL $\beta$ mercaptoethanol in the hood.

(http://www.abcam.com/ps/pdf/protocols/stripping\%20for\%20reprobing.pdf).

\subsection{Cell and Animal Treatments}


1. Vehicle (sesame oil), E2 (200 $\mu \mathrm{g} / \mathrm{mL}$ or $10 \mu \mathrm{g} / 50 \mu \mathrm{L}$ ), G-1 (agonist of GPR30, $6 \mu \mathrm{g} / \mathrm{mL}$ or 0.3 $\mu \mathrm{g} / 50 \mu \mathrm{L}$ ), G-15 (antagonist of GPR30, $30 \mu \mathrm{g} / \mathrm{mL}$ or $1.5 \mu \mathrm{g} / 50 \mu \mathrm{L}$ ). Dissolve E2, G-1, and G15 slowly in sesame oil at $55^{\circ}$ for $24 \mathrm{~h}$. Store in aliquots at $-20^{\circ} \mathrm{C}$ and remove aliquots for use; avoid frequent freeze-thaw cycles.

\section{Methods}

\subsection{Tissue Procurement}

1. Gonadectomize adult mice (male or female) ( 27-30 grams). Allow 1 week for the mice to recover from the surgery and to ensure that gonadal hormones have cleared the circulation. Make sure that all animal protocols conform to ethical procedures and are

2. Inject gonadectomized mice with $50 \mu \mathrm{L}$ of vehicle, E2 $(300 \mu \mathrm{g} / \mathrm{kg}), \mathrm{G}-1(10 \mu \mathrm{g} / \mathrm{kg})$ subcutaneously. (It may be necessary to perform dose-response analyses with selected agents to determine the most appropriate treatment.) To determine whether the effect of G-1 or of E2 is specific, pre-treat the animals with a 5-fold molar excess of the GPR30 antagonist, G-15, $(250 \mu \mathrm{g} / \mathrm{kg}) 30 \mathrm{~min}$ before the administration of either E2 or G-1.

3. Euthanize the animals 30 min after injection.

4. Quickly remove the brain.

5. Wash the brain in cold $1 x$ PBS.

6. Dissect the brain region of interest (e.g., ventral hippocampus) using a brain block. Alternatively, samples can be obtained from cultured primary hypothalamic neonatal male mouse cells or from neural cell lines. We have used final concentrations of $10^{-9} \mathrm{M}$ E2 and $10^{-8} \mathrm{M}$ G-1 in cell culture. In order to block the effect of G-1, we have used both 
10 and 100 fold excess of the antagonist; i.e., $10^{-7}$ or $10^{-6} \mathrm{M}$ G-15. In all cases, the drugs or hormones are dissolved in DMSO and the concentration of DMSO added to wells in $0.1 \%$ or less of the volume of the media present in the well containing the cells.

\subsection{Making the Lysate}

1. Follow instructions to make complete lysis buffer. Make sure lysis buffer is ready at $4{ }^{\circ} \mathrm{C}$ or on ice prior to use.

2. To prepare lysate from cell culture:

a. Remove media from cells and rinse two times with $0.5-1 \mathrm{~mL}$ of ice-cold PBS.

b. After removing the last rinse, add $50-100 \mu \mathrm{L}$ of complete lysis buffer to cells (see Note 10).

c. Allow complete lysis buffer to sit on cells for 1-3 min.

d. Using a pipette tip or a cell scraper, disrupt the cells and scrape them from the bottom of the dish. Limit the number of bubbles generated.

e. Pipette out buffer and cell mixture and transfer to a microcentrifuge tube.

f. Spin tubes with cells for $10 \mathrm{~min}$ at $13,000-16,000 \mathrm{xg}$ in a refrigerated centrifuge set to $4^{\circ} \mathrm{C}$.

g. Remove the supernatant and transfer to a new microcentrifuge tube.

h. Store lysate at $-20^{\circ} \mathrm{C}$ for up to a week or at $-80^{\circ} \mathrm{C}$ for long-term storage.

3. To prepare lysate from brain tissue:

a. Dissect out the brain region of interest.

b. Place tissue into a microcentrifuge tube containing $50-200 \mu \mathrm{L}$ of complete lysis buffer (see Note 11). 
c. Homogenize the tissue manually using a hand-held pestle. Alternatively, a motorized pestle or tissue sonicator can be used. These methods will provide a higher protein yield.

d. When the tissue is dissociated, centrifuge the microcentrifuge tubes for $30 \mathrm{~min}$ at $13,000-16,000 \mathrm{xg}$ in a refrigerated centrifuge set to $4^{\circ} \mathrm{C}$.

e. Pipette out the supernatant and transfer to a new microcentrifuge tube.

f. Store lysate at $-20^{\circ} \mathrm{C}$ for up to a week or at $-80^{\circ} \mathrm{C}$ for long-term storage.

\subsection{Making Two Gels}

1. Place short plates and $1.0 \mathrm{~mm}$ spacer plates into casting module. Secure with clip.

2. Temporarily place the 10 -well plastic comb in place between the plates. Using a wax pencil or marker, draw a small line on the short glass plates where the end of the teeth will be for the well comb. This mark serves as the fill level for the separating gel. Remove the comb.

3. To make $10 \%$ resolving gel (see Note 12), combine $5 \mathrm{~mL} 1.5 \mathrm{M}$ Tris- $\mathrm{HCl}(\mathrm{pH} 8.8), 6.6 \mathrm{~mL}$

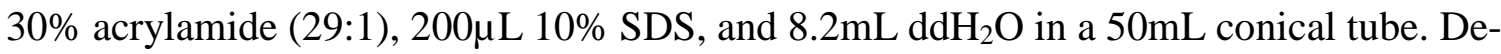
gas with suction for 15 min (see Notes 13 and 14).

4. Add $100 \mu \mathrm{L} 10 \%$ APS and $10 \mu \mathrm{L}$ TEMED to initiate polymerization of the gel. Make sure to use a fresh aliquot of $10 \%$ APS each day. Gently rock to mix.

5. Fill the plates with the separating gel up to the line drawn earlier.

6. Pour or pipet enough water saturated isobutanol onto the separating gel to make a complete layer across the gel.

7. Allow the gel to polymerize for $30-45 \mathrm{~min}$. If the isobutanol is on the gel any longer than 45 min it starts drying out the gel. 
8. During the last $15 \mathrm{~min}$ of the polymerization of the separating gel, begin making the stacking gel. Combine 1.25mL 0.5M Tris-HCl (pH 6.8), 670 $\mu \mathrm{L} 30 \%$ acrylamide (29:1), $50 \mu \mathrm{L} 10 \%$ SDS, and $3 \mathrm{~mL} \mathrm{ddH}_{2} \mathrm{O}$ in a $15 \mathrm{~mL}$ conical tube. Degas as described above.

9. Once the separating gel has polymerized, pour out the isobutanol from the top of the gels. Rinse 2 times with $\mathrm{ddH}_{2} \mathrm{O}$ (see Note 15).

10. Immediately before use, add $25 \mu \mathrm{L} 10 \%$ APS and $5 \mu 1$ TEMED to the stacking gel. Gently rock to mix.

11.Pour the stacking gel on top of the separating gel.

12. Insert the combs into the liquid stacking gel gently in a slight left to right movement. Make sure there are no bubbles under the comb.

13. Allow to polymerize for $45 \mathrm{~min}$ to an hour.

14. The gel can be used immediately after it has completely polymerized. Alternatively, it can be wrapped in paper towels soaked with running buffer, wrapped in plastic wrap or in a plastic bag, and stored at $4^{\circ} \mathrm{C}$ until use, up to 2 weeks.

\subsection{Gel Electrophoresis and Blotting}

For more information on preparing protein samples for electrophoresis, please see Note

16.

1. Place two gels, well-comb side in, into the running apparatus. If using only one gel, place the plastic dam on the second side.

2. Place the gel apparatus into the tank and fill it with $1 \mathrm{X}$ Running Buffer (see Note 17).

3. Gently remove the combs from the wells. To do this, you may have to shift the combs back and forth a little to help release the wells.

4. Wash out the wells by flushing each well with running buffer a few times using a pipette. 
5. Heat protein samples at $95^{\circ} \mathrm{C}$ for $8 \mathrm{~min}$. After boiling, quickly centrifuge sample tubes to ensure that all liquid has returned to the bottom of the tube.

6. Load $10 \mu \mathrm{L}$ of protein standards/ladder (see Note 18 ).

7. Load protein samples into respective wells.

8. In any remaining unfilled wells, add a proportionate amount of loading dye.

9. Place the lid on the apparatus making sure to match red to red connectors and black to black connectors.

10. Run the gel at $120 \mathrm{~V}$ until there is enough separation between the ladder bands to properly see your band of interest.

11. When the gel is approximately halfway through the run (the dye front is halfway down the gel), cut as many pieces of PVDF membrane as needed to the size of the gel (see Note 19).

12. Soak the membranes in methanol for one min. Rinse off with $\mathrm{ddH}_{2} \mathrm{O}$. Place in $1 \mathrm{X}$ Transfer Buffer for at least 15 min prior to use (see Note 20).

13. Place the sponges and blot paper ( 2 each per gel) in a box of $1 \mathrm{X}$ Transfer Buffer to allow them to soak for at least 15 min prior to use. Make sure remaining 1X Transfer Buffer stays in the refrigerator until use.

14. After the electrophoresis run has completed, remove the gel apparatus and the glass plates. Carefully separate the short plate from the spacer plate using a plastic tool.

15. Remove the stacking gel from the running gel with a piece of plastic and scrape the stacking gel away. 
16. Gently remove the gel from the glass plates keeping track of the top of the gel. Place the gel in a small box filled with $\mathrm{ddH}_{2} \mathrm{O}$ to rinse off excess SDS. Swish briefly, remove water, and replace with $1 \mathrm{X}$ Transfer Buffer.

17. Remove running buffer and rinse out the tank with $\mathrm{ddH}_{2} \mathrm{O}$ to remove excess SDS.

18. Insert the blotting module and an ice pack into the tank and place it on a stir plate. Insert a small magnetic stir bar and a small amount of $1 \mathrm{X}$ Transfer Buffer. Make sure the stir bar can spin freely before continuing any further.

19. Assemble the transfer sandwich on the open transfer cassette with the black side down. Start building the sandwich on the black side. Place down one sponge and top it with one piece of blot paper. Gently transfer the gel to the top of the filter paper keeping track of the top of the gel. It is preferable to place the protein marker/ladder at the top, with the top portion where the wells were facing the inner side of the cassette. Make sure to pour liberal amounts of $1 \mathrm{X}$ Transfer Buffer over and between every layer to ensure that the sandwich remains moist and air bubbles do not form. It is recommended to do this step over a secondary plastic container to catch excess buffer overflow.

20. Carefully place a piece of presoaked PVDF membrane over the gel, ensuring that no bubbles form between the membrane and the gel.

21. Top with another piece of blot paper and another sponge.

22. Close the sandwich cassette and insert it with the black side of the cassette facing the black side of the transfer apparatus.

23. Fill the tank with $1 X$ Transfer Buffer. Replace the lid. Transfer at a 300mA for $60-90$ $\min$. 
24. Do not allow the transfer to get too warm. Check the transfer every 15 min to ensure that it does not overheat. The entire transfer apparatus can be placed into a bucket of ice on the stir plate to keep the temperature down longer to allow for more complete transfers (see Note 21).

\subsection{Blocking and Antibody Incubation}

1. After the transfer is complete, disassemble the sandwiches and remove the membrane. Place the membrane into a small plastic box containing $7-10 \mathrm{~mL}$ of $5 \%$ BSA/TTBS (see Note 22).

2. Place the box on orbital shaker for $1 \mathrm{~h}$ (see Note 23).

3. When the blocking step is near completion, begin making the primary antibody mixtures to image phospho-ER $\alpha$ on the membrane. $5 \% \mathrm{BSA} / \mathrm{TTBS}$ is used to make all primary antibody mixtures. Allow 7-10mL per blot. (If using systems like the LiCOR Odyssey system with primaries of different species, co-incubation of primary antibodies of different species is possible.)

The antibody dilutions, incubation times, and incubation temperatures are:

a. Rabbit anti-phospho-ER $\alpha$ (Ser 118): Dilute 1:4,000. Incubate for $1 \mathrm{~h}$ at room temperature on orbital shaker.

b. Rabbit anti-phospho-ER $\alpha$ (Ser 167): Dilute 1:750. Incubate overnight at $4^{\circ} \mathrm{C}$ on orbital shaker.

4. Following incubation in primary antibody, rinse the blot in TTBS four times, 10 min per wash on an orbital shaker. The box should be approximately one-third full with TTBS.

5. Prepare the secondary antibody cocktail using 5\% BSA/TTBS. Dilute Goat anti-Rabbit HRP conjugated secondary antibody to 1:50,000 (see Note 9). 
6. Incubate blots in secondary antibody cocktail for one $\mathrm{h}$ at room temperature on an orbital shaker.

7. Following incubation in secondary antibody, rinse the blot in TTBS six times, $10 \mathrm{~min}$ per wash on orbital shaker. Box should be approximately one-third full with TTBS.

8. Visualize the blot as desired (see Note 24).

9. Strip the anti-phospho-ER $\alpha$ antibodies from the membrane using protocol and buffer from Abcam (see Note 25) in preparation for imaging nonphosphorylated ER $\alpha$.

10. Following the required rinses in water, wash the blot with TTBS four times, 10 min per wash on orbital shaker.

11. Re-block membrane using 5\% BSA in TTBS (see Note 26).

12. When the blocking step is near completion, begin making the ER $\alpha$ primary antibody mixture using 5\% BSA in TTBS.

a. If the protein source was cell culture lysates: Dilute ER $\alpha$ antibody 1:4,000. Incubate the membrane in this primary antibody overnight at $4^{\circ} \mathrm{C}$ on an orbital shaker.

b. If the protein source was tissue lysates: Dilute ER $\alpha$ antibody 1:1,000. Incubate the membrane in this primary antibody overnight at $4^{\circ} \mathrm{C}$ on orbital shaker.

13. Rinse in TTBS four times, 10 min per wash on orbital shaker.

14.Prepare the secondary antibody mixture using $5 \%$ BSA/TTBS. Dilute Goat anti-Rabbit HRP conjugated secondary antibody to 1:50,000 when the protein source is cell culture lysates or 1:20,000 when the protein source is tissue lysates.

15. Incubate blots in secondary antibody cocktail for one $\mathrm{h}$ at room temperature on orbital shaker.

16. Rinse with TTBS four times, 10 min per wash on orbital shaker. 
17. Develop blot as desired (see Note 24 and Note 27).

18. The expected results may vary depending on the dose. However, we have seen an increase in phosphorylated ER $\alpha$ at S118 in ventral hippocampal tissues treated with the GPR30 agonist, G-1, as compared to the vehicle treated tissue. In addition, we expect that this increase is blocked in tissues treated with the GPR30 antagonist, G-15. Though the phospho-S118 ER $\alpha$ antibody detects a strong band of $66 \mathrm{kd}$, the antibodies that detect total ER $\alpha$ often detect bands of other sizes such as $52 \mathrm{kd}, 46 \mathrm{kd}, 60 \mathrm{kd}$ and sometimes higher molecular weight bands of about $72 \mathrm{kd}$ in the mouse brain. The 66kd band detected by this antibody in tissue is often lower in intensity to the other bands. This is in contrast to the scenario in uterine tissue from the rat or mouse, where the $66 \mathrm{kd}$ band detected by the total $\mathrm{ER} \alpha$ antibody is the predominant band.

\section{Notes}

1. Ultrapure water $(\sim 18 \mathrm{M} \Omega)$ should be used whenever $\mathrm{ddH}_{2} \mathrm{O}$ is required.

2. PBS made in the lab from a standard recipe works just as well as premade PBS for these purposes.

3. Whether or not cell scrapers are useful will have to be determined by the experimenter and the method in which the cells are cultured. Small areas of cells (e.g., 24-well plates) are easily scraped using a $200 \mu \mathrm{L}$ pipette tip instead of a scraper.

4. These pestles can be used to mechanically dissociate the tissue. Other methods of tissue homogenization can be used.

5. A $6 \mathrm{~N} \mathrm{HCl}$ solution can be used for adjusting $\mathrm{pH}$. 
6. Stirring the $10 \%$ SDS solution can create a large amount of bubbles. It is recommended to stir this slowly or wait for the bubbles to settle down before adjusting with $\mathrm{ddH}_{2} \mathrm{O}$ to final volume.

7. PVDF membranes work well for the protocol described. However, the membrane should be chosen based on methods of developing the final product. For instance, a low fluorescence membrane is recommended when using infrared secondary antibodies.

8. Plastic containers should be as close to the size of the blot as possible to reduce waste of reagents. Our lab has found that the boxes used to sell push pins are of the perfect size for blots made using a Mini-PROTEAN 3 or Tetra system.

9. The method described here is based on using HRP substrates and film to develop the final product. However, there are alternative methods of developing a Western blot and the secondary antibody chosen should match the developing method.

10. The exact amount of complete lysis buffer used is highly dependent on cell density and the surface area of the culture dish. It is recommended to run a few trials to find the optimal amount of lysis buffer for an experiment.

11. Similar to making cell culture lysates, the amount of complete lysis buffer needed varies greatly on brain region and sample size. It is recommended to run test trials to determine the optimal amount of lysis buffer for the sample. Particularly large samples of tissue may be subdivided into multiple tubes to facilitate homogenization.

12. Both phosphorylated versions of ER $\alpha$ described in this protocol work well with either $7.5 \%$ or $10 \%$ resolving gels. If another protein needs to be probed on the same blots as phospho-ER $\alpha$, a different percentage gel can be used to optimize the other protein without causing problems in phospho-ER $\alpha$ detection. 
13. Degassing a gel improves the quality of results, but is not necessary if no methods of degassing are available.

14. To make a 7.5\% resolving gel, combine $3 \mathrm{~mL} 1.5 \mathrm{M}$ Tris- $\mathrm{HCl}(\mathrm{pH} 8.8), 3 \mathrm{~mL} 30 \%$ acrylamide (29:1), $120 \mu \mathrm{L} 10 \%$ SDS, and $5.75 \mathrm{~mL} \mathrm{ddH}_{2} \mathrm{O}$. Add $120 \mu \mathrm{L} 10 \%$ APS and $12 \mu \mathrm{L}$ TEMED to initiate polymerization of the gel.

15. Take care to remove as much of the isobutanol as possible.

16. The volume of each component that is used depends on the quantity (in $\mu \mathrm{g}$ ) of protein you want to load and the total volume of the mixture you want to load. The amount of protein loaded is determined through optimization work. We have found that $20 \mu \mathrm{g}$ is sufficient for detection of most proteins we use but this can be adjusted as needed. As far as total volume of the mixture, you can load an absolute maximum volume of $30 \mu \mathrm{L}$ into a 10 well gel. However, it is easier and more desirable to load smaller volumes to minimize spillover between lanes. The ideal loading volume is $20 \mu \mathrm{L}$ for 10 well gels. The amount of Laemmli Sample loading buffer (SLB) used is $1 / 3$ of the total volume of the mixture and the amount of RIPA used is the volume required to dilute each sample to the same total volume.

17. The fill line will be labeled on the tank if using a Mini-PROTEAN Tetra system or to the top of the gels if using a Mini-PROTEAN 3 system.

18. Specialized loading tips are recommended. These tips facilitate complete transfer of sample to wells. However, $200 \mu \mathrm{L}$ tips are an acceptable substitute.

19. It is recommended to have a cardboard template cut for this purpose.

20. Old pipette tip boxes make excellent containers for this part of the protocol. 
21. Constant voltage can be used instead of constant amperage for the transfer. This choice is dependent on time and other variables. The selection of either constant voltage or constant amperage should not alter the end result when working with the described antibodies.

22. Coomassie solution can be used to counterstain the gels to check for transfer of protein or quality of remaining protein.

23. It is not recommended to block the blots for an extended period of time. Extended blocking can enhance background or lead to protein transfer from the blots. Additionally, the use of 5\% BSA/TTBS may be inappropriate for different developing methods and cause exogenous background (e.g., infrared detection methods).

24. We recommend using SuperSignal West Femto Chemiluminescent Substrate and developing the blot with film.

25. The harsh stripping protocol by Abcam is very effective. Perform this procedure in a fume hood and make sure to rinse the blot adequately with TBST afterwards since traces of $\beta$-mercaptoethanol may damage the antibody.

26. We recommend checking the effectiveness of the antibody strip by reincubating the blot in secondary antibody and visualizing. If old primary antibodies were stripped from the membrane, no signal should be detected. We have not seen any loss of protein from the membrane using this protocol.

27. A control protein should be probed to allow for normalization of protein bands to control for any variations in loading. 
Acknowledgments: This work was supported by funding supplied by the NSF CAREER IOS1053716 to N.V. and a Louisiana Board of Regents Fellowship to K.P. 


\section{References}

1. Enmark, E., Gustafsson, J.A. (1999) Oestrogen receptors - an overview. J Intern Med 246 (2), $33-138$

2. Nilsson, S., Makela, S., Treuter, E., et al. (2001) Mechanisms of estrogen action. Physiol Rev 81(4), 1535-1565

3. Vasudevan, N., Pfaff, D.W. (2007) Membrane-initiated actions of estrogens in neuroendocrinology: emerging principles. Endocr Rev 28(1), 1-19

4. Faresse, N. (2014) Post-translational modifications of the mineralocorticoid receptor: How to dress the receptor according to the circumstances? J Steroid Biochem Mol Biol 143, 334-342 5. Lee, J.H., Lee, M.J. (2012) Emerging roles of the ubiquitin-proteasome system in the steroid receptor signaling. Arch Pharm Res 35(3), 397-407

6. Abdel-Hafiz, H.A., Horwitz, K.B. (2014) Post-translational modifications of the progesterone receptors. J Steroid Biochem Mol Biol 140, 80-89

7. Lannigan, D.A. (2003) Estrogen receptor phosphorylation. Steroids 68, 1-9

8. Weigel, N.L. (1996) Steroid hormone receptors and their regulation by phosphorylation. Biochem J 319( Pt 3), 657-667

9. Acconcia, F., Ascenzi, P., Bocedi, A., et el. (2005) Palmitoylation-dependent estrogen receptor alpha membrane localization: regulation by 17beta-estradiol. Mol Biol Cell 16(1), 231237

10. LeGoff, P., Montano, M.M., Schodin, D.J., Katzenellenbogen, B.S. (1994) Phosphorylation of the human estrogen receptor. Identification of hormone-regulated sites and examination of their influence on transcriptional activity. J Biol Chem 269, 4458-4466 
11. Kato, S., Endoh, H., Masuhiro, Y., et al. (1995) Activation of the estrogen receptor through phosphorylation by mitogen-activated protein kinase. Science 270, 1491-1494

12. Joel, P.B., Traish, A.M., Lannigan, D.A. (1995) Estradiol and phorbol ester cause phosphorylation of serine 118 in the human estrogen receptor. Mol Endocrinol 9(8), 1041-1052 13. Joel, P.B., Smith, J., Sturgill, T.W., Fisher, T.L., Blenis, J., Lannigan, D.A. (1998) pp90rsk1 regulates estrogen receptor-mediated transcription through phosphorylation of Ser-167. Mol Cell Biol 18 (4), 1978-1984

14. Martin, M.B., Franke, T.F., Stoica, G.E., et al. (2000) A role for Akt in mediating the estrogenic functions of epidermal growth factor and insulin-like growth factor I. Endocrinology 141(12), 4503-4511

15. Duplessis, T.T., Williams, C.C., Hill, S.M., Rowan, B.G. (2011) Phosphorylation of Estrogen Receptor alpha at serine 118 directs recruitment of promoter complexes and gene-specific transcription. Endocrinology 152(6), 2517-2526

16. Skliris, G.P., Nugent, Z.J., Rowan, B.G., Penner, C.R., Watson, P.H., Murphy, L.C. (YEAR) A phosphorylation code for oestrogen receptor-alpha predicts clinical outcome to endocrine therapy in breast cancer. Endocr Relat Cancer 17(3), 589-597

17. Murphy, L.C., Skliris, G.P., Rowan, B.G., et al. (2009) The relevance of phosphorylated forms of estrogen receptor in human breast cancer in vivo. J Steroid Biochem Mol Biol 114(1-2), 90-95

18. Kato, S.S. (2001) Estrogen receptor-mediated crosstalk with growth factor signaling pathways. Breast Cancer 8(1), 3-9 
19. Patrone, C., Gianazza, E., Santagati, S., Agrati, P., Maggi, A. (1998) Divergent pathways regulate ligand-independent activation of ER alpha in SK-N-BE2C neuroblastoma and COS-1 renal carcinoma cells. Mol Endocrinol 12(6), 835-841

20. Held, J.M., Britton, D.J., Scott, G.K., et al. (2012) Ligand binding promotes CDK-dependent phosphorylation of ER-alpha on hinge serine 294 but inhibits ligand-independent phosphorylation of serine 305. Mol Cancer Res 10(8), 1120-1132

21. Bunone, G., Briand, P.A., Miksicek, R.J., Picard, D. (1996) Activation of the unliganded estrogen receptor by EGF involves the MAP kinase pathway and direct phosphorylation. EMBO $J 15,2174-2183$

22. Clark, S., Rainville, J., Zhao, X., Katzenellenbogen, B.S., Pfaff, D., Vasudevan, N. (2014) Estrogen receptor-mediated transcription involves the activation of multiple kinase pathways in neuroblastoma cells. J Steroid Biochem Mol Biol 139, 45-53

23. Maggiolini, M., Picard, D. (2010) The unfolding stories of GPR30, a new membrane-bound estrogen receptor. J Endocrinol 204(2), 105-114

24. Prossnitz, E.R., Maggiolini, M. (2009) Mechanisms of estrogen signaling and gene expression via GPR30. Mol Cell Endocrinol 308(1-2), 32-38

25. Brailoiu, E., Dun, S.L., Brailoiu, G.C., et al. (2007) Distribution and characterization of estrogen receptor G protein-coupled receptor 30 in the rat central nervous system. $J$ Endocrinol 193(2), 311-321

26. Burai, R., Ramesh, C., Shorty, M., et al. (2010) Highly efficient synthesis and characterization of the GPR30-selective agonist G-1 and related tetrahydroquinoline analogs. Org Biomol Chem 8(9), 2252-2259 
27. Dennis, M.K., Burai, R., Ramesh, C., et al. (2009) In vivo effects of a GPR30 antagonist. Nat Chem Biol 5(6), 421-427

28. Dennis, M.K., Field, A.S., Burai, R., et al. (2011) Identification of a GPER/GPR30 antagonist with improved estrogen receptor counterselectivity. J Steroid Biochem Mol Biol 127(3-5), 358-366

29. Hart, D., Nilges, M., Pollard, K., et al. (2014) Activation of the G-protein coupled receptor 30 (GPR30) has different effects on anxiety in male and female mice. Steroids 81, 49-56

30. Hart, S.A., Snyder, M.A., Smejkalova, T., Woolley, C.S. (2007) Estrogen mobilizes a subset of estrogen receptor-alpha-immunoreactive vesicles in inhibitory presynaptic boutons in hippocampal CA1. J Neurosci 27(8), 2102-2111

31. Bondar, G., Kuo, J., Hamid, N., Micevych, P. (2009) Estradiol-induced estrogen receptoralpha trafficking. J Neurosci 29(48), 15323-15330

32. Dominguez, R., Micevych, P. (2010) Estradiol rapidly regulates membrane estrogen receptor alpha levels in hypothalamic neurons. J Neurosci 30(38), 12589-12596

33. Chen, D., Washbrook, E., Sarwar, N., et al. (2002) Phosphorylation of human estrogen receptor alpha at serine 118 by two distinct signal transduction pathways revealed by phosphorylation-specific antisera. Oncogene 21(32), 4921-4931

34. Snyder, M.A., Smejkalova, T., Forlano, P.M., Woolley, C.S. (2010) Multiple ERbeta antisera label in ERbeta knockout and null mouse tissues. J Neurosci Methods 188(2), 226-234 